\title{
Pemahaman Guru Bahasa Indonesia SMA di Kabupaten Mesuji terhadap Kurikulum 2013 Edisi Revisi
}

\author{
Oleh: \\ Munaris; Bambang Riadi \\ Program Studi Pendidikan Bahasa dan Sastra Indonesia \\ FKIP Universitas Lampung
}

\begin{abstract}
The purpose of this study is to describe the understanding of high school Indonesian teachers in Mesuji District towards the revised edition 2013 curriculum. The method used in this research is descriptive evaluative. The results of questionnaires from 27 respondents indicate that teachers 'understanding of Permendikbud in 2016 number 20 with Good category dominates by almost 50\%, teachers' understanding of Permendikbud in 2016 number 21 with Good and Simple dominate by $50 \%$ at Permendikbud 2016 number 22 with the category of Good dominate with the amount more than $50 \%$, then the teacher's understanding of Permendikbud year 2016 number 23 with Good category dominate with amount more than 50\%. The results can be concluded that the level of understanding of high school Indonesian language teacher in Mesuji District to the curriculum 2013 edition of the revision has been qualified.
\end{abstract}

Keywords: teacher's understanding, curriculum, Mesuji

\begin{abstract}
Abstrak. Tujuan penelitian ini adalah mendeskripsikan pemahaman guru Bahasa Indonesia sekolah menengah atas di Kabupaten Mesuji terhadap kurikulum 2013 edisi revisi. Metode yang digunakan dalam penelitian ini adalah deskriptif evaluatif. Hasil angket dari 27 responden menunjukkan bahwa pemahaman guru terhadap Permendikbud tahun 2016 nomor 20 dengan kategori Baik mendominasi dengan jumlah hampir mendekati 50\%, pemahaman guru terhadap Permendikbud tahun 2016 nomor 21 dengan kategori Baik dan Cukup mendominasi dengan jumlah 50\%, pada Permendikbud tahun 2016 nomor 22 dengan kategori Baik mendominasi dengan jumlah lebih dari 50\%, selanjutnya pemahaman guru terhadap Permendikbud tahun 2016 nomor 23 dengan kategori Baik mendominasi dengan jumlah lebih dari 50\%. Hasil penelitian dapat disimpulkan bahwa tingkat pemahaman guru bahasa Indonesia sekolah menengah atas di Kabupaten Mesuji terhadap kurikulum 2013 edisi revisi sudah mumpuni.
\end{abstract}

Kata kunci: pemahaman guru, kurikulum, Mesuji 


\section{PENDAHULUAN}

Berbicara kurikulum berarti berbicara kualitas dan tujuan pendidikan yang akan dicapai. Kurikulum menjadi gambaran awal bagaimana sebuah sistem pendidikan akan dibangun. Wajah sistem pendidikan akan tergambar jelas dari kurikulum yang akan dikembangkan. Kemudian direalisasikan dalam skenario pembelajaran pada masing-masing Satuan Tingkat Pendidikan Sekolah Dasar dan Menengah.

Kurikulum secara luas dapat diberi pengertian segala hal yang direncanakan dalam dunia pendidikan. Segala hal tersebut meliputi seluruh pengalaman belajar yang dapat memengaruhi peserta didik. Dalam pengertian yang sempit, kurikulum merupakan sekumpulan mata pelajaran yang harus ditempuh oleh peserta didik pada jenjang tertentu. Dengan demikian, kurikulum merupakan salah satu bagiam dalam sistem pendidikan. Sebagai salah satu sistem pendidikan, kurikulum mempunyai peran penting sebagai panduan pelaksanaan pendidikan dan pembelajaran.

Dalam dunia pendidikan di Indenesia sejak tahun 2013 telah diberlakukan Kurikulum 2013 (K-13) untuk menggantikan Kurikulum Tingkat Satuan Pendidikan (KTSP). Pergantingan tersebut tidak berjalan mulus. Penggunaan K13 belum sampai diterapkan di seluruh sekolah Indonesia, pemerintah memutuskan untuk menunda pemberlakuan Kurikulum 2013. Oleh karena itu, ada sekolah yang tetap melanjutkan pembelajaran dengan Kurikulum 2013, ada yang sudah menggunakan, tetapi kembali ke KTSP, dan ada pula yang tetap KTSP karena memang belum pernah menggunakan Kurikulum 2013.

Kurikulum 2013 yang penggunaannya sempat ditunda tersebut direvisi dan diberlakukan pada 2016. Antara Kurikulum 2013 dengan Kurikulum 2013 edisi revisi terdapat berbagai perbedaan. Dalam konteks pembelajaran guru sebagai penerjemah Kurikulum 2013 edisi revisi sudah seharusnya memahami Kurikulum 2013 edisi revisi tersebut. Pemahaman guru tersebut sangat berdampak pada perencanaan pembelajaran, pelaksanaan pembelajaran, dan penilaian dalam pembelajaran.

Panduan penerapan Kurikulum 2013 edisi revisi tersebut dituangkan dalam Permendikbud tahun 2016, yaitu nomor 20 s.d. 23. Oleh karena itu, pemahaman guru terhadap Kurikulum 2013edisi revisi ini diarahkan pada pemahaman guru terhadap Permendikbud tersebut berserta penjelasan-penjelasan yang diberikan oleh para narasumber terkait dengan Kurikulum 2013. Permendikbud tersebut berisi mengenai standar kompetensi lulusan, standar isi, standar proses, dan 
standar penilaian dalam pendidikan. Keempat Permendikbud tersebut merupakan landasan yuridis pelaksanaan Kurikulum 2013edisi revisi.

Menjadi sebuah keharusan untuk menerjemahkan keempat ladasan yuridis pelaksanaan Kurikulum 2013 yang telah dimandatkan melalui Permendikbud. Mengejawantahkan empat landasan tersebut bukan perkara yang mudah, maka dari itu perlu adanya kaji tindak dan penelitiajn yang dapat mengukur tingkat pemahan guru sebagai eksekutor terhadap Permendikbud tersebut.

Penelitian terhadap pemahaman Kurikulum 2013 revisi sudah pernah dilakukan pada Guru Bahasa Indonesia di Bandarlampung pada tahun 2016 dengan didanai DIPA FKIP Unila. Penelitian tersebut juga menitik fokuskan pada Permendikbud tahun 2016 nomor 21, 22,23, dan 23 sebagai landasan yuridis. Berdasarkan hasil analisis berdasarkan pemahaman guru terhadap Permendikbud Nomor 20 Tahun 2016, pemahaman guru Standar Kompetensi Kelulusan Pendidikan Dasar dan Menengah sudah termasuk dalam level kategori Baik, pemahaman tentang Standar Isi Pendidikan Dasar dan Menengah masuk dalam level kategori Baik dan Cukup, pemahaman tentang Standar Proses Pendidikan Dasar dan Menengah masuk dalam level kategori Baik dan Cukup, pemahaman tentang Standar Penilaian Pendidikan Dasar dan Menengah memiliki porsi yang hampir sama dari kategori Sangat Baik, Baik, dan Cukup.

Melihat hasil penelitian yang sudah dilakukan pada guru Bahasa Indonesia di Bandarlampung, peneliti tertarik bagaimana jika penelitian dilakukan di lakukan di daerah. Kabupaten menjadi daerah tujuan penelitian dengan maksud ingin mengetahui bagaimana kondisi pemahaman guru di daerah terhadap Permendikbud 2016. Apakah kondisi pemahaman antara guru di kota dan guru di kabupaten memiliki kesenjangan. Berdasarkan hal tersebut maka penelitian pemahaman perlu dilakukan di Kabupaten Mesuji.

\section{METODE PENELITIAN}

Jenis penelitian ini adalah penelitian deskriptif evaluatif. Penelitian evaluatif pada dasarnya merupakan bagian dari penelitian terapan. Penelitian evaluasi dimaksudkan untuk mengukur keberhasilan suatu program, produk atau kegiatan tertentu (Danim, 2000).

Penelitian ini diarahkan untuk menilai keberhasilan manfaat, kegunaan, sumbangan dan kelayakan suatu program kegiatan dari suatu unit/ lembaga tertentu. Penelitian deskriptif, merupakan gambaran atau lukisan secara sistematis, faktual dan akurat mengenai fenomena atau hubungan antar fenomena yang 
diselidiki. Pendekatan yang digunakan dalam penelitian adalah pendekatan evaluatif, dimana peneliti bermaksud mengumpulkan data tentang implementasi kebijakan. Penelitian evaluatif pada dasarnya terpusat pada rekomendasi akhir yang menegaskan bahwa suatu obyek evaluasi dapat dipertahankan, ditingkatkan, diperbaiki atau bahkan diberhentikan sejalan dengan data yang diperoleh. Dalam penelitian ini dilaksanakan untuk memperoleh data serta menghasilkan kesimpulan yang ada di lapangan sehubungan dengan evaluasi pemahaman guru terhadap Kurikulim 2013.

\section{Data dan Sumber Data}

Data dalam penelitian ini berupa hasil dari angket tertutup berupa pilihan ganda yang telah diberikan. Menurut Saifuddin Azwar (2007: 91), bahwa data penelitian digolongkan sebagai data primer dan data skunder. Data primer atau data tangan pertama adalah data yang diperoleh langsung dari subjek penelitian dengan menggerakkan alat pengukuran atau alat pengambilan data langsung dari subjek sebagai sumber informasi yang dicari, seperti observasi yang bersifat langsung sehingga akurasinya lebih tinggi, akan tetapi seringkali tidak efisien karena memperolehnya diperlukan sumber data yang lebih besar. Sedangkan data sekunder atau data tangan kedua adalah data yang diperoleh lewat pihak lain, tidak langsung diperoleh oleh peneliti dari subjek penelitiannya. Data sekunder biasanya berbentuk dokumentasi atau data laporan yang telah tersedia, sehingga mempunyai efisiensi yang tinggi akan tetapi kadang-kadang kurang akurat.

Data yang penulis gunakan sebagai sumber data primer adalah informasi atau data yang berasal dari subjek penelitian, dalam hal ini adalah guru bahasa indonesia di Bandarlampung. Jenis data yang diperoleh adalah data kuantitatif.

\section{Pengumpulan dan Analisis Data}

Teknik pengumpulan data yang digunakan dalam penelitian ini adalah teknik komunikasi yaitu cara mengumpulkan data melalui kontak atau hubungan pribadi antara pengumpul data dengan sumber data (Margono, 2010: 165). Dalam pelaksanaannya dapat dibedakan ke dalam teknik komunikasi langsung yang berupa interview dan teknik komunikasi tidak langsung yang berupa kuesioner (sistem angket). Dalam penelitian ini, peneliti menggunakan teknik komunikasi yang tidak langsung (angket). 


\section{HASIL PENELITIAN}

Pada bab ini akan dipaparkan secara deskriptif hasil angket yang telah dibagikan kepada guru terkait pemahaman terhadap Permendikbud tahun 2016 revisi nomor 20, 21, 22, dan 23.

\section{Pemahaman Guru Bahasa Indonesia SMA di Kabupaten Mesuji terhadap Permendikbud Nomor 20 Tahun 2016}

Berdasarkan hasil penelitian dari 27 guru yang memperoleh skor Baik berjumlah 12 orang, artinya kategori 12 orang tersebut jika dipersentasikan sebesar 44, 44\% dari 27 guru. Kemudian yang memperoleh skor dengan kategori $\mathbf{C u k u p}$ berjumlah 9 guru, artinya dari jumlah tersebut jika di konversikan ke dalam persentase sebesar 33, 33\% dari jumlah total 27 guru. Selanjutnya guru yang memperoleh skor dengan kategori Kurang berjumlah hanya 5 orang, jika jumlah tersebut dikonversikan dalam presentase keseluruhan jumlah guru yang ada maka nilainya 18,5\%. Nilai maksimum yang diperoleh berdasarkan hasil angket adalah 9, sedangkan untuk nilai minimum adalah 4. Nilai rata-rata yang diperoleh guru terhadap pemahaman Permendikbud Nomor 20 Tahun 2016 sebesar 7, 29. Untuk pemahaman guru terhadap Permendikbud dengan kategori Baik mendominasi dengan jumlah hamper mendekati 50\%, dengan demikian dapat disimpulkan bahwa tingkat pemahaman guru bahasa indonesia SMA di Kabupaten Mesuji sudah mumpuni.

\section{Pemahaman Guru Bahasa Indonesia SMA di Kabupaten Mesuji terhadap Permendikbud Nomor 21 Tahun 2016}

Berdasarkan hasil penelitian dari 27 guru yang memperoleh skor Baik berjumlah 12 orang, artinya jumlah 12 orang tersebut jika dipersentasikan sebesar 44,4\% dari 27 guru. Guru yang memperoleh skor dengan kategori Cukup berjumlah 12 orang, artinya jika jumlah tersebut jika dikonversikan dalam presentase sebesar 44,4,\% dari jumlah total 27 guru. Selanjutnya guru yang memperoleh skor dengan kategori Kurang berjumlah 3 orang dengan persentase 11,11\%. Nilai maksimum yang diperoleh berdasarkan penyebaran angket adalah 8 , sedangkan nilai minum yang diperoleh adalah 4 . Nilai rata-rata yang diperoleh guru terhadap pemahaman Permendikbud Nomor 21 Tahun 2016 sebesar 6,29. Untuk pemahaman guru terhadap Permendikbud dengan kategori Baikdan Cukupmendominasi dengan jumlah 50\%, dengan demikian dapat disimpulkan bahwa tingkat pemahaman guru bahasa indonesia SMA di Bandarlampung sudah mumpuni namun perlu adanya peningkatan untuk pemahaman Standar Isi dalam pendidikan menengah. 


\section{Pemahaman Guru Bahasa Indonesia SMA di Kabupaten Mesuji terhadap Permendikbud Nomor 22 Tahun 2016}

Berdasarkan penelitian dari 27 guru yang memperoleh skor Baik berjumlah 5 orang, artinya kategori 19 orang dengan persentase sebesar 70,37\% dari 27 guru. Selanjutnya guru yang memperoleh skor dengan kategori Cukup berjumlah 8 orang, artinya jika jumlah tersebut jika dikonversikan dalam presentase sebesar 29,6\% dari jumlah total 27 guru. Skor rata-rata yang diperoleh guru terhadap pemahaman Permendikbud Nomor 23 Tahun 2016 sebesar 13,33 kemudian skor akhir 66,66. Untuk pemahaman guru terhadap Permendikbud dengan kategori Baik mendominasi dengan jumlah lebih dari 50\%, dengan demikian dapat disimpulkan bahwa tingkat pemahaman guru bahasa indonesia SMA di Kabupaten Mesuji terhadap Standar Proses Pendidikan Dasar dan Menengah sudah mumpuni.

\section{Pemahaman Guru Bahasa Indonesia SMA di Kabupaten Mesuji terhadap Permendikbud Nomor 23 Tahun 2016}

Berdasarkan penelitian tersebut dari 27 guru yang memperoleh skor Baikberjumlah 18 orang, artinya kategori orang tersebut jika dipersentasikan sebesar 66,7\% dari 27 guru. Guru yang memperoleh skor dengan kategori Cukup berjumlah 5 orang, artinya jika jumlah tersebut jika dikonversikan dalam presentase sebesar $18,5 \%$ dari jumlah total 27 guru. Selanjutnya guru yang memperoleh skor dengan kategori Kurang berjumlah 4 orang, jika jumlah tersebut dikonversikan dalam presentase keseluruhan jumlah guru yang ada maka nilainya $14,8 \%$. Nilai maksimum yang diperoleh guru dari hasil angket adalah 9 , sedangkan nilai minimum yang diperoleh oleh guru adalah 4 . Nilai skor rata-rata yang diperoleh guru terhadap pemahaman Permendikbud Nomor 23 Tahun 2016 sebesar 7,62. Untuk pemahaman guru terhadap Permendikbud dengan kategori Baik mendominasi dengan jumlah lebih dari 50\%, dengan demikian dapat disimpulkan bahwa tingkat pemahaman guru bahasa indonesia SMA di Mesuji terhadap Standar Penilaian Pendidikan Dasar dan Menegah memenuhi kriteria.

\section{PENUTUP}

Berdasarkan hasil analisis berdasarkan pemahaman guru di Kabupaten Mesuji terhadap Permendikbud Nomor 20 Tahun 2016, Nomor 21 Tahun 2016, Nomor 22 Tahun 2016, Nomor 23 Tahun 2016 berkaitan dengan Kurikulum 2013 (K-13) Edisi Revisi, peneliti menyimpulkan sebagai berikut.

1. Hasil pemahaman guru terhadap Permendikbud Nomor 20 Tahun 2016 tentang Standar Kompetensi Kelulusan Pendidikan Dasar dan Menengah sudah termasuk dalam level kategori Baik dan Cukup, kedua kategori tersebut 
memiliki porsi yang sama. Namun, perlu peningkatan pemahaman supaya tidak ada guru yang masuk dalam kategori Kurang.

2. Hasil pemahaman guru terhadap Permendikbud Nomor 21 Tahun 2016 tentang Standar Isi Pendidikan Dasar dan Menengah masuk dalam level kategori Baik dan Cukup, masih ada guru yang masuk dalam kategori Kurang.

3. Hasil pemahaman guru terhadap Permendikbud Nomor 22 Tahun 2016 tentang Standar Proses Pendidikan Dasar dan Menengah masuk dalam level kategori Baik, hanya ada beberapa guru yang masuk dalam kategoro Cukup, tidak ada guru yang masuk dalam kategori Kurang. Melihat kondisi tersebut hanya perlu menambah pemahan terhadap Permendikbud tersebut.

4. Hasil pemahaman guru terhadap Permendikbud Nomor 23 Tahun 2016 tentang Standar Penilaian Pendidikan Dasar dan Menengah dapat dikatakan sudah Baik, lebih dari 50\% guru sudah memahami terkait dengan standar penilaian. Namun masih ada guru yang mendapat nilai Cukup dan Kurang, meski dengan presentasi yang sangat kecil.

\section{Rekomendasi}

Berdasarkan perolehan skor-skor guru masih tampak ada yang sudah memahami dan belum sepenuhnya memahami dari Permendikbud No 20 tahun 2016, No 21 tahun 2016, No 22 tahun 2016, No 23 tahun 2016. Perlu dilakukan adanya tindak lanjut yang serius dari Dinas Pendidikan dan Kebudayaan Pemerintah Provinsi Lampung, Dinas Pendidikan dan Kebudayaan Pemerintah Kabupaten Mesuji berupa seminar, diklat, workshop, pelatihan atau kegiatan yang berkelanjutan serta mendukung terlaksananya pemahaman terhadap Permendikbud tersebut.

\section{DAFTAR PUSTAKA}

Danim, Sudarwan. 2000. Pengantar Studi Penelitian Kebijakan. Jakarta: Bumi Aksara

Hamalik. 2008. Kurikulum dan Pembelajaran. Jakarta: Bumi Aksara Margono. 2010.Metodologi Penelitian Pendidikan. Jakarta: Rineka Cipta

Permendikbud Nomor 20 Tahun 2016 (Standar Kompetensi Lulusan Pendidikan Dasar dan Menengah)

Permendikbud Nomor 21 Tahun 2016 (Standar Isi Pendidikan Dasar dan Menengah)

Permendikbud Nomor 20 Tahun 2016 (Standar Proses Pendidikan Dasar dan Menengah)

Permendikbud Nomor 20 Tahun 2016 (Standar Penilaian Pendidikan Dasar dan Menengah)

Tarigan . 1993.Strategi Pengajaran dan Pembelajaran. Bandung: Angkasa

Team Pembina Mata Kuliah Didaktik Metodik. 1995.

Saifuddin Azwar. 2007. Metode Penelitian. Yogyakarta: Pustaka Pelajar 